\title{
Peluang Pengembangan Voluntourism Berbasis Masyarakat di Hutan Mangrove Batu Lumbang, Suwung, Pemogan, Denpasar
}

Septianing Tyas a, 1 , I Nyoman Sukma Arida a, 2

${ }^{1}$ Septianningtyas35@gmail.com, ${ }^{2}$ sukma_arida@unud.ac.id

a Program Studi Sarjana Destinasi Pariwisata, Fakultas Pariwisata, Universitas Udayana, Jl. Dr. R. Goris, Denpasar, Bali 80232 Indonesia

\begin{abstract}
The Mangrove Batu lumbang as conservation areas where live so many variety of flora and also has so beautiful view. Although the mangrove has not yet defined it as a tourist attraction, there are few tourist visitors. Assets or potential have been particularly supportive to develop as alternative tourism but there are some issues about garbage and waste. Voluntourism has become one of the best types of alternative tourism to develop. Voluntourism or volunteer tourism is a form of tourism where tourists use leisure time as volunteers and donators on conservation projects in an attraction. The purpose of this study is to identify the chances of voluntourism development in the mangrove forest Batu Lumbang based communities to help the ecosystem and grow the communities also give a new experience for tourist. The study used qualitative descriptive methods. The result of this study is the mangrove forest Batu Lumbang fillup some of the criteria of voluntourism activity. The criteria of the study based on the criteria of the global tourism business industries. The limits of this research are the time to finding data due to a covid-19 outbreak.
\end{abstract}

Keyword: voluntourism; Hutan Mangrove Batu Lumbang; Responsible Tourism

\section{PENDAHULUAN}

Sebagai salah satu destinasi wisata terbaik di dunia menurut TripAdvisor tahun 2020 adalah Bali. Pertumbuhan ekonomi pariwisata yang pesat dan peningkatan jumlah kunjungan wisatawan tiap tahunnya membuat Bali atraksi wisata semakin bervariatif (Anom, dkk., 2017). Hal tersebut pula mendukung metamorfosa produk pariwisata Bali yang bercorak budaya menjadi lebih beragam. Ditandai dengan munculnya jenis wisata baru seperti wisata petualangan, kuliner, pedesaan, bahari, MICE, dan sebagainya (Putra dan Paturusi: 2017).

Pada tahun 2019, kunjungan wisatawan mancanegara ke Bali mencapai angka 6.275.210 orang dimana mengalami peningkatan sejumlah sekitar 200.000 orang dari tahun sebelumnya (Badan Pusat Statistik Provinsi Bali: Mei 2020). Dewasa ini sektor pariwisata pun menjadi unggulan dan menyerap tenaga kerja yang besar di Bali. Menurut SAKERNAS (Survey Angkatan Kerja Nasional) BPS Provinsi Bali 2017, 760.093 orang bekerja di sektor pariwisata tentunya angka ini terus meningkat tiap tahunnya, merupakan angka tertinggi diantara sektor pertanian dan jasa sosial kemasayarakatan.

Dibalik dampak positif dibidang ekonomi yang dirasakan masyarakat Bali, tingginya kunjungan wisatawan membuat penyelenggaraan pariwisata Bali mengarah ke mass tourism. Praktik mass tourism sejatinya membawa beberapa dampak negatif seperti kemacetan, kerusakan lingkungan, dan sedikitnya mulai merusak tatanan budaya Bali (Sinta, 2015).

Hal ini apabila terus terjadi tentunya dapat menjadi kerugian besar bagi destinasi itu sendiri. Praktik mass tourism yang terjadi di Bali dapat membawa dampak yang kurang baik terhadap lingkungan apabila wisatawan yang datang tidak turut terlibat menjaga lingkungan destinasi yang dikunjunginya. Contohnya seperti, tidak membuang sampah sembarangan maupun limbah lainnya, mematuhi aturan di daya tarik tempat suci, dan lain sebagainya.

Salah satu lokasi yang menajalankan praktik pariwisata namun dengan juga menjaga alam sekitar ialah Hutan Mangrove Batu Lumbang, Suwung, Pemogan, Denpasar. Sebagai area konservasi, pada awalnya penyelenggaraan kegiatan wisata di lokasi ini dilatarbelakangi oleh keterbatasan dana operasional dari masyarakat lokal dalam mengelola kegiatan konservasi lngkungan. Masyarakat pengelola tersebut tergabung dalam Kelompok Nelayan Segara Guna Batu Lumbang dan Kelompok Masyarakat Pengawas Minawerdi Batu Lumbang di bawah Dinas Ketahanan Pangan dan Perikanan serta Dinas Lingkungan Hidup Provinsi Bali. Masalah yang dihadapi lokasi ini ialah sebagai muara sungai menyebabkan adanya sampah kiriman yang perlu diambil secara berkala dan keterbatasan dana operasional. Masyarakat menyadari pentingnya menjaga lingkungan khususnya area Hutan Mnagrove yang merupakan sabuk hijau dalam menangkal abrasi maupun tsunami. Adapun kegiatan wisata yang diselenggarakan ialah susur mangrove menggunakan kano atau boat. Meskipun demikian, belum banyak wisatawan yang mengetahui lokasi tersebut dan masyarakat setempat masih belum paham betul dalam pengembangan pariwisata disana. Hanya ada beberapa komunitas yang datang untuk membantu melakukan pengambilan sampah sambil susur mangrove menggunakan kano.

Adapun jenis pariwisata alternatif yang memiliki peluang dikembangkan di Hutan Mangrove Batu Lumbang ialah Voluntourism. Jenis wisata ini menggabungkan kegiatan volunteer atau sukarelawan dan pariwisata. Memiliki potensi alam yang indah, 
lokasi ini dapat dikembangkan agar menjadi pilihan wisatawan minat khusus dan mengurangi penumpukan wisatawan di wilayah Badung Selatan. Dimana pada kegiatannya wisatawan memanfaatkan waktu luang sebagai relawan dan donatur pada proyek konservasi yang bertujuan untuk menyediakan alternative pariwisata berkelanjutan yang dapat membantu pengembangan masyarakat, penelitian ilmiah dan pemulihan ekologis (Brumbaugh, 2010 dalam APEC, 2018). Dengan potensi alam yang dimiliki Hutan Mangrove Batu Lumbang diharapkan dapat menjadi pilihan wisata baru bagi wisatawan dan membantu masayarakat dalam penanganan sampah kiriman. Maka dari itu, penelitian ini penelitian ini dilakukan untuk mengetahui peluang pengembangan voluntourism berbasis masyarakat di Hutan Mangrove Batu Lumbang, Suwung, Denpasar.

Penelitian ini juga medukung penelitian sebelumnya berupaa jurnal yang berjudul "Voluntourism As An Alternative Tourism In The Global Area" oleh Sidhi Turker. Pada penelitian ini membahas mengenai pengembangan voluntourism di era global dan aspek-aspek yang ada di dalamnya. Pada penelitin oleh Sidhi Turker disebutkan bahwa semua destinasi wisata dunia memiliki peluang pengembangan voluntourism sebagai suatu upaya untuk memperbaiki kualitas citra pariwisata dan menangkap keuntungan dari model voluntourism sebagai alternatif pariwisata di era global.

\section{METODE PENELITIAN}

Penelitian ini dilakukan untuk mengetahui peluang pengembangan voluntourism di Hutan Mangrove Batu Lumbang berbasis masayrakat dengan menyesuaikan terhadap kriteria aktivitas voluntourism itu sendiri. Adapun alasan dipilihnya Hutan Mangrove Batu Lumbang sebagai lokasi penelitian kali ini ialah : (1) Potensi alam yang indah namun masyarakat belum mengembangkan wisata secara maksimal ; (2) Adanya penyelenggaraan aktivitas konservasi oleh kelompok masyarakat lokal namun kekurangan dana operasional; (3) Minimnya kunjungan wisatawan.

Terdapat batasan permasalahan yang kemudian disebut sebagai ruang lingkup penelitian untuk mempertegas arah aspek data yang akan diteliti pada penelitian ini. Ruang lingkup penelitian ini adalah kriteria aktivitas voluntourism oleh The Global Tourism Business Scheme yang terdiri atas 10 aspek yakni ; compulsory, management and marketing, social involvement and communication, energy efficiency, water efficiency, purchasing enviromentally friendly goods, waste minimisation, transport, natural and cultural heritage, innovation.

Merupakan bagian dari TAHURA Ngurah Rai, lokasi Hutan Mangrove Batu Lumbang terbilang cukup strategis karena berada di dekat Pantai Kuta dan juga fasilitas pariwisata lainnya dengan akses masuk melalui waduk Muara Nusa Dua. Memiliki luas wilayah kurang lebih 150 hektare, terdiri dari hamparan hutan bakau yang mengelilingi muara sungai yang mengarah ke laut. Hutan ini dihuni oleh biota laut yang beragam, apabila melakukan susur mangrove wisatawan dapat menyaksikan pemandangan indah tol Bali Mandara. Aktivitas keseharian masayrakat lokal yang sangat peduli terhadap lingkungan juga bersinergi dengan kriteria aktivitas voluntourism. Penelitian ini dilakukan sejak 4 Oktober - 4 November 2019.

Penelitian ini menggunakan metode penelitian kualitatif yang menghasilkan data deskriptif berupa kata-kata tertulis dari orang atau prilaku yang diamati (Bodgan dan Taylor dalam Basrowi dan Suwandi, 2008). Sumber data dalam penelitian ini dibagi menjadi dua, yaitu data primer yang diperoleh secara langsung saat melakukan penelitian dan data sekunder yang diperoleh secara tidak langsung misalnya melalui dokumen (Sugiyono, 2016) seperti dari berbagai sumber bacaaan, seperti jurnal, skripsi, buku, dan sebagainya. Data dalam penelitian ini diperoleh melalui, observasi yakni mengamati fenomena yang terjadi kemudian mencatat perilaku dan kejadin yang sebenarnya (Suryawan, dkk., 2017), berikutnya melalui wawancara yakni mengajukan pertanyaan kepada informan (Moleong, 2014), dan dokumentasi yang merupakan catatan peristiwa yang sudah berlalu (Sugiyono 2016). Penentuan informan dalam penelitian ini menggunakan purposive sampling yaitu informan dari Kelompok Nelayan Segara Guna Batu Lumbang dan Kelompok Masyarakat Pengawas Minawerdi Batu Lumbang serta beberapa anggota dari komunitas GenBI Bali yang mengikuti kegiatan pengambilan sampah sambil susur mangrove. Teknik analisis data (Miles dan Huberman dalam Sugiyono 2016) yakni reduksi data, display dan penarikan kesimpulan atau verifikasi.

\section{HASIL DAN PEMBAHASAN}

Pada awalnya ada beberapa aktivitas nelayan di Hutan Mangrove Batu lumbang yang merusak lingkungan seperti menangkap ikan dengan potasium dan penebangan pohon bakau. Maka dari itu dibentuklah POKMASWAS Minawerdhi Batu Lumbang (Kelompok Masyarakat Pengawas) oleh Dinas Kelautan dan Perikanan Provinsi Bali untuk mengawasi dan mengedukasi Kelompok Nelayan Segara Guna Batu Lumbang agar tidak merusak lingkungan. Kedua kelompok masayarakat ini kemudian bersinergi dalam mengelola Hutan Mangrove Batu Lumbang dengan baik hingga mencapai prestasi di kancah nasional sebagai juara 1 pada tahun 2010 sebagai kelompok nelayan dan juara 2 pada tahun 2010 
sebagai organisasi lingkungan hidup terbaik dan pada tahun 2015 meraih juara 1 sebagai organisasi lingkungan hidup terbaik.

Banyaknya prestasi yang diraih oleh Kelompok nelayan Segara Guna Batu Lumbang dan POKMASWAS minawerdhi Batu Lumbang membuat pemerintah sering melakukan kunjungan dan memberikan bantuan fasilitas seperti boat, alat komunikasi dan juga sarana berupa bangunan balai dan semi kantor sebagai secretariat POKMASWAS dan kelompok nelayan untuk mengadakan pertemuan atau melakukan aktivitas lain. Namun demikian, tidak ada dana operasional yang diberikan oleh pemerintah. Selain dana operasional, permasalahan lain yang dihadapi oleh kelompok nelayan dan POKMASWAS ialah sampah. Sebagai muara sungai, banyak sampah kiriman dan tersangkut di pohon bakau sekitar Hutan Mangrove sehingga diperlukan pengambilan sampah secara berkala. Volume sampah yang awalnya sangat tinggi lambat laun berkurang. Pada tahun 2014 mencapai 12 ton sampah yang berhasil di angkut dan pada tahun 2019 hanya mencapai 2 ton kemudian sampah tersebut dibuang ke Tempat Pembuangan Akhir (TPA).

Beberapa komunitas seperti Keluarga Mahasiswa Katolik Universitas Udayana (KMK UNUD), Jegeg Bagus Universitas Udayana (JBU UNUD), Generasi Baru Indonesia (GenBI) Bali dan lainnya pun turut mengikuti kegiatan pengambilan sampah tersebut. Berdasarkan wawancara bersama mahasiswa yang tergabung dalam komunitas GenBI Bali yang tengah melakukan kegiatan pengambilan sampah sambil susur mangrove, mengaku bahwa kegiatan ini menjadi aktivitas peduli lingkungan yang seru karena lokasi Hutan Mangrove yang indah seperti yang dapat dilihat pada Gambar 1.

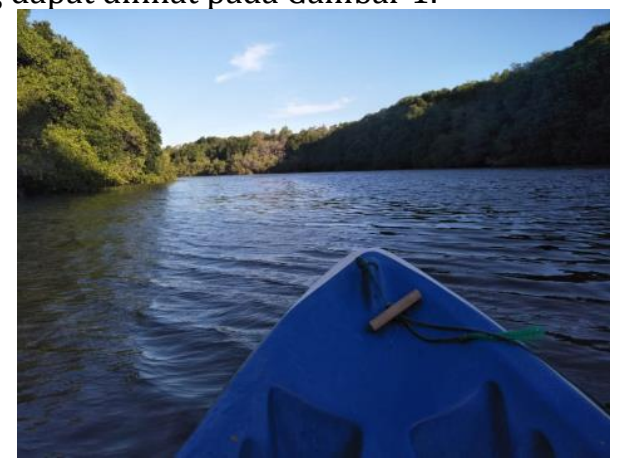

Gambar 1 Komunitas GenBI Bali Melakukan Susur Mangrove Sambil Mengambil Sampah Tahun 2019

Sumber: Dokumentasi Pribadi

Para mahasiswa tersebut pun dengan sukarela membayar biaya sewa kano untuk dapat melakukan kegiatan tersebut, namun sebelum kegiatan berlangsung para pengelola memberikan materi berupa sejarah dan potensi Hutan Mangrove Batu Lumbang serta visi untuk konservasi lingkungan yang dimiliki para pengelola dan tidak ketinggalan aturan dalam melakukan pengambilan sampah sambil susur mangrove seperti yang terlihat pada Gambar 2 dan 3. Untuk mengatasi keterbatasan dana operasional ini, kelompok nelayan dan POKMASWAS menjalankan aktivitas pariwisata untuk mendapatkan uang tambahan. Hal tersebut berdasarkan hasil pemikiran dan saran dari beberapa masyarakat setempat yang berkecimpung di dunia pariwisata. Lokasi Hutan Mangrove Batu Lumbang yang sangat strategis memang sangat cocok untuk dikembangkan sebagai tempat wisata. Lokasinya berdekatan dengan beberapa pusat perbelanjaan dan pusat kegiatan pariwisata seperti Pantai Kuta yang sudah menjadi tujuan wisata utama bagi wisatawan bila berkunjung ke Bali. Sehingga Hutan Mangrove Batu Lumbang sangat berpotensi menjadi tujuan wisata baru.

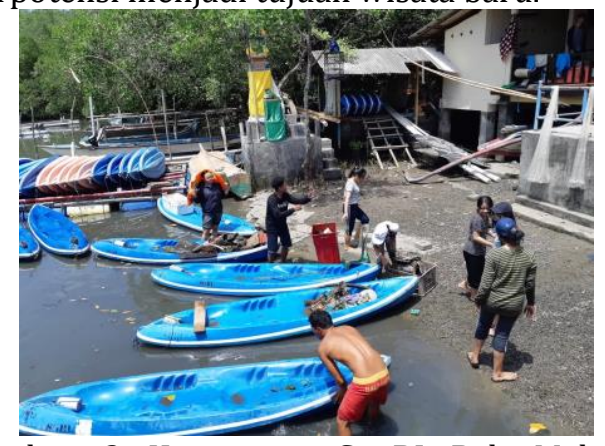

Gambar 2 Komunitas GenBI Bali Melakukan Susur Mangrove Sambil Mengambil Sampah Sumber: Dokumentasi Pribadi Tahun 2019

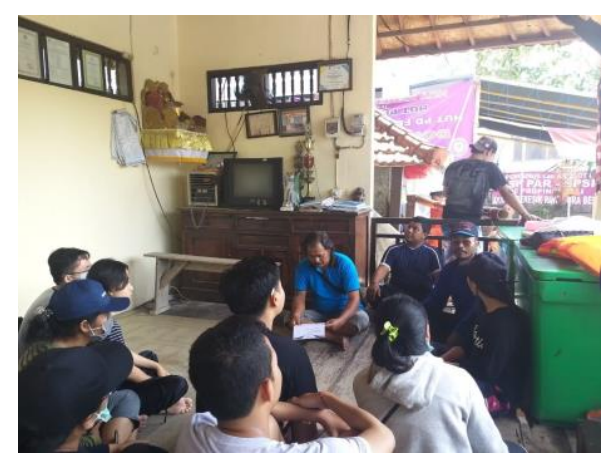

Gambar 3 Pembekalan oleh Pengelola kepada Komunitas GenBI Bali Tahun 2019

Sumber: Dokumentasi Pribadi

Jenis wisata voluntourism dapat dikatakan sesuai dengan visi dari pengelola Hutan Mangrove Batu Lumbang. Kegiatan voluntourism juga dapat dikategorikan sebagai responsible tourism dimana wisatawan melakukan pembangunan yang berkelanjutan melalui pariwisata. Responsible tourism sendiri 
bertujuan untuk mengatasi masalah-masalah krusial secara lokal dalam agenda pembangunan berkelanjutan (Godwin, 2013 dalam Manh Cuong $\mathrm{Vu}, 2015$ ). Maka dari itu jenis wisata ini cocok untuk di kembangkan di Bali sebagai alternative pariwisata massal dan di Hutan Mangrove Batu Lumbang khususnya untuk membantu masyarakat mengembangkan pariwisata sekaligus mengatasi masalah sampah dan mensejahterakan kehidupan masyarakat lokal yang mayoritas merupakan nelayan.

Pada penelitian ini, untuk melihat peluang pengembangan voluntourism di Hutan Mangrove Batu Lumbang digunakan kriteria aktivitas voluntolurism dari The Global Tourism Business Scheme (www.green-tourism.com dalam Turker, 2014) yang disesuaikan dengan keadaan di lapangan. Adapun kriteria yang dimaksud ialah ;

(1) Compulsory yakni menjaga komitmen untuk meningkatkan linkungan yang berkelanjutan.

(2) Management and Marketing yakni adanya pengelolaan lingkungan yang baik dalam manajemen dan pemasaran, baik itu kesadaran dari pengelola dan staff yang terlibat, pemantauan, pencatatan, serta pelatihan khusus.

(3) Social Involvement and Communication yakni turut terlibat dalam kegiatan sosial dan juga komunikasi dengan menyiapkan beragam aktivitas bagi wisatawan yang terkait konservasi, mempromosikan upaya konservasi di website, pendidikan dan pelatihan untuk masyarakat serta kegiatan sosial lainnya.

(4) Energy Efficiency yakni efisensi energi cahaya, pemanas dan alat serta penggunaan sumber energy baru.

(5) Water Efficiency yakni efisiensi penggunaan energy air seperti pemanfaatan air hujan, penggunaan pembersih ramah lingkungan, penggunaan alat yangmemakan energy rendah dan pemeliharaan air yang baik.

(6) Purchasing Environmentally Friendly Goods yakni Pembelian dan menggunakan jasa atau barng yang ramah terhadap lingkungan. Contohnya seperti menggunakan barang yang mudah di daur ulang atau dari bahan daur ulang serta mempromosikan makanan dan minuman khas lokal.

(7) Waste Minimisation yakni meminimalisir dampak penggunaan limbah seperti meminimalkan penggunaan barang yang susah di daur ulang secara alami seperti plastic, kaca, logam dan sebagainya.

(8) Transport yakni mempromosikan penggunaan transportasi lokal atau tranpsportasi umum, memberikan pilihan tranportasi bersepeda dan transportasi dengan bahan bakar ramah lingkungan lainnya. Hal ini bertujusn untuk mengurangi penggunaan pribadi dari wisatawan.

(9) Natural and Cultural Heritage yakni menjaga warisan budaya dana lam yang asli serta meningkatkan keragaman hayati baik flora maupun fauna yang ada dan memberikan informasi mengenai hal tersebut kepada wisatawan.

(10)Innovation yakni adanya inovasi untuk kepentingan keberlanjutan bisnis.

Berdasarkan hasil observasi, wawancara dan dokumentasi yang dilakukan, menyesuaikan dengan kriteria aktivitas volntourism dari The Global Tourism Business Scheme dapat dijelaskan bahwa adapun kriteria aktivitas voluntourism yang telah dipenuhi di Hutan Mangrove Batu Lumbang ialah Compulsory yakni menjaga komitmen untuk meningkatkan keberlanjutan kinerja lingkungan telah nyata dilakukan oleh masayrakat kelompok nelayan dan POKMASWAS dengan kegiatan pengambilan sampah serta penanaman pohon bakau. Social Involvement and Communication yakni keterlibatan dalam berbagai kegiatan sosial dan komunikasi dengan menyiapkan aktivitas bagi wisatawan melalui berbagai bentuk yang telah dilakukan oleh kelompok nelayan dan POKMASWAS ialah dengan mengadakan kegiatan susur mangrove sambil mengangkut sampah bagi berbagai komunitas cinta lingkungan namun masih kurang di bagian promosi dari sosial media resmi pengelola, hanya dari komunitas yang melakukan kegiatan di Hutan Mangrove tersebut. Energy efisiensi dilakukan oleh kelompok nelayan dan POKMASWAS karena dalam kegiatan bernelayan secara tradiosional menggunakan jarring dan kano yang hanya membutuhkan tenaga manusia. Water efficiency dimana penggunaan energy rendah serta menggunakan pembersih ramah lingkungan juga diterapkan oleh pengelola Hutan Mangrove Batu Lumbang ini. Natural and Cuktural Heritage telah dilakukan pengelola Hutan Mangrove Batu Lumbang dengan melestarikan flora serta fauna dan warisan budaya masayrakat sekitar memberikan pengetahuan tersebut kepada wisatawan maupun komunitas yang datang. Waste minimisation yang dilakukan oleh POKMASWAS dengan mengawasi nelayan agar tidak tidak menangkap ikan dengan bahan peledak yang dapat mencemari lingkungan.

Sedangkan kriteria aktivitas voluntourism yang belum terpenuhi oleh Hutan Mangrove Batu Lumbang ialah Management and Marketing yakni pencatatan yang baik terhadap kunjungan wisatawan dan kurangnya pelatihan khusus terkait pariwisata kepada kelompok nelayan dan 
POKMASWAS. Kemudian Purchasing environmentally friendly goods masih belum dilakukan sepenuhnya oleh masayarakat setempat sehingga hal ini yang perlu diperbaiki karena, Transport yakni sejauh ini belum ada akses untuk angkutan umum menuju lokasi namun wisatawan dapat bersepeda disekitaran lokasi yakni di Waduk Muara Penida yang merupakan akses menuju lokasi dan kriteria terakhir yang belum dipenuhi ialah Innovation yakni belum ada inovasi baru yang dilakukan untuk meningkatkan keberlanjutan bisnis.

Berikut merupakan matriks peluang pengembangan voluntourism di Hutan Mangrove Batu Lumbang berdasarkan kriteria aktivitas voluntourism:

Tabel 1 Peluang Pengembangan Voluntourism di Hutan Mangrove Batu Lumbang

\begin{tabular}{|c|c|c|c|}
\hline No. & Kriteria & Mementii & Betum Memenuhi \\
\hline 1 & Compulsory & $\sqrt{ }$ & \\
\hline 2 & Management and Marketing & & $\checkmark$ \\
\hline 3 & Social Involvement and Communication & $\checkmark$ & \\
\hline 4 & Energy - efficiency & $\checkmark$ & \\
\hline 5 & Water-efficiency & $\checkmark$ & \\
\hline 6 & Purchasing environmentally friendly goods and services & & $\checkmark$ \\
\hline 7 & Waste minimisation by encourraging & $\checkmark$ & \\
\hline 8 & Transport & & $\checkmark$ \\
\hline 9 & Natural and Cultural Heritage & $\sqrt{ }$ & \\
\hline 10 & Innovation & & $\checkmark$ \\
\hline
\end{tabular}

Sumber: Hasil Penelitian, 2019

Dengan demikian, dari sepuluh kriteria aktivitas voluntourism yang ada, Hutan Mnagrove Batu lumbang telah memenuhi enam kriteria tersebut sehingga dapat dikatakan berpeluang dalam pengembangan Hutan Mangrove sebagai Voluntourism berbasis masyarakat dan perlu memenuhi empat kriteria yang belum terpenuhi. Dengan pengembangan voluntourism di Hutan Mangrove Batu Lumbang, diharapkan dapat membantu permasalahan yang dihadapi masyarakat setempat dan menjadi pengalaman yang baru bagi wisatawan serta melestarikan lingkungan.

\section{KESIMPULAN}

Hutan Mangrove Batu Lumbang memenuhi 6 kriteria dari 10 kriteria aktivitas voluntourism dari The Global Tourism Business Scheme yakni Compulsory, Social Involvement and Communication, Energy Efficiency, Water Efficiency, Waste Minimisation ,Natural and Cultural Heritage. Sehingga dapat dikatakan Hutan Mangrove Batu Lumbang berpeluang untuk pengembangan voluntourism berbasis masyarakat.

Adapun saran yang dapat disampaikan ialah pengelola perlu memenuhi beberapa kriteria dari aktivitas voluntourism yang belum terpenuhi agar dapat berjalan secara maksimal. adapun kegiatan yang dapat dicanangkan untuk wistawan volunteer ialah pengangkutan sampah meggunakan kano sembari susur mangrove, penanaman pohon bakau, pengelolaan sampah, dan juga pendidikan bagi anakanak dari nelayan. Selain itu wisatawan juga bisa melakukan konservasi penyu di Pulau Serangan dengan menaiki boat terlebih dahulu dari Hutan Mangrove Batu Lumbang. Wisatawan dapat pula bersepeda disekitaran Waduk Muara Penida yang merupakan akses masuk ke Hutan Mangrove ini. Selain itu wisatawan juga dapat melihat proses persembahyangan masyarakat di Pura Dalem Luhur Segara Batu Lumbang yang cukup besar dan berdekatan dengan lokasi. Tentunya dalam setiap kegiatan tersebut masayrakat pengelola dapat bersinergi dengan wisatawan volunteer. Wisatawan juga dapat mengikuti keseharian nelayan dalam menangkap ikan dan sebagainya. Pihak kelompok nelayan dan POKMASWAS perlu menjalin kerjasama dengan Yayasan di Bali yang bergerak di bidang voluntourism untuk mendistribusikan voluntourist ke lokasi ini. Selain itu, pembuatan website resmi lokasi dan paket wisata voluntourism yang lebih rinci. Kemudian menjadikan rumah warga sebagai homestay bagi wisatawan volunteer. Tidak mustahil bila wisatawan volunteer yang dapat membantu masyarakat dalam pengembangan konservasi serta kegiatan wisata maupun menjadi donatur sarana serta prasarana yang diperlukan. Wisatawan yang datang membayar sebagai sukarelawan untuk dapat melakukan berbagai kegiatan konservasi maupun kegiatan lain yang telah disediakan. Paket wisata yang dibuat menyediakan kegiatan bagi wisatawan, fasilitas tempat tinggal (dapat berupa homestay dari masyarakat lokal), makanan dan minuman, serta transportasi untuk menjemput dan mengantarkan wisatawan untuk kegiatan volunteering.

\section{DAFTAR PUSTAKA/REFERENSI}


Anonim. 2017. Travel and Tourism Economic Impact 2018 Indonesia. United Kingdom : World Travel Tourism Council

Anom, I. P., Suryasih, I. A., Nugroho, S., \& Mahagangga, I. G. A. O. (2017). Turismemorfosis: Tahapan selama seratus tahun perkembangan dan prediksi pariwisata Bali. Jurnal Kajian Bali (Journal of Bali Studies), 7(2), 59-80. google scholar link.

APEC, 2018. Voluntourism Best Practices : Promoting Inclusive Community Based Suistainable Tourism Intiatives. Selandia Baru : APEC Tourism Working

Bali. Denpasar: Pustaka Larasan.

Basrowi dan Suwandi. 2008. Memahami Penelitian Kualitatif. Jakarta : Rineka

Eadington, WR and Smith, V. 1992. "The Emergency of Alternative Form of Tourism" dalam Suwena 2010. "Format Pariwisata Masa Depan. Denpasar

Moleong, L. 2014. Metodologi Penelitian Kualitatif. Bandung: PT Remaja Rosdakarya.

Putra, I Nyoman Darma, Syamsul Alam Paturusi. 2017. Kajian-Kajian Mikro Metamorfosis Pariwisata Bali. Putra, I Nyoman Darma, Syamsul Alam Paturusi (Ed.). Metamorfosis Pariwisata Bali : Tantangan Membangun Pariwisata Berkelanjutan Bali. Denpasar: Pustaka Larasan.

San, Robertus, Ni Made Oka Karini, I GPB Mananda. 2016. Partisipasi Masyarakat dalam Pengembangan Daya Tarik Wisata Pantai Pandawa, Kabupaten Badung, Desa Kutuh, Kuta Selatan. Jurnal IPTA 4 (1): 37 - 42.

Sugiyono. 2016. Metode Penelitian Kuantitatif, Kualitatif dan R\&d. Bandung;PT Alfabet.

Suryawan, I. B., \& Mahagangga, I. G. A. O. (2017). Penelitian Lapangan 1. Denpasar: Cakra Media dan Fakultas Pariwisata Universitas Udayana.

Trisila, Slamat. 2014. Biografi Pengusaha Hotel sebagai Sumber Sejarah Pariwisata Bali. JUMPA, 1 (1): 201 - 2016.

Turker, Sidhi. 2014. Voluntourism Sebuah Upaya Pengembangan Kualitas Pariwisata Di Era Global Tourism. Jurnal Ekonomi dan Pariwisata Program Studi Manajemen Universitas Universitas Dhyana Pura Bali.

\section{Sumber dari Internet}

https://kumparan.com/kumparantravel/selamatbali-dinobatkan-jadi-destinasi-wisata-terbaik-duniaversi-tripadvisor-1tvCARum6S

(Diunduh pada tanggal 09 November 2020, Pukul 09.00 WITA)

https://bali.bps.go.id/statictable/2018/02/09/21/j umlah-wisatawan-asing-ke-bali-menurut-bulan1982-2019.html
(Diunduh pada pada tanggal 3 November 2019, pukul 10.00 WITA)

https://bali.bps.go.id/publication/2018/10/01/stat istik-ketenagakerjaan-provinsi-bali-2017.html Diunduh pada pada tanggal 3 November 2019, pukul 10.15 WITA) 